DOI: $10.32702 / 2307-2105-2019.5 .9$

UDC: 338.28

\author{
V. Zalizko
}

Doctor of Economics, Professor of the Department of Enterprise Economics,

University of the State Fiscal Service of Ukraine, Irpin, Ukraine

ORCID: 0000-0001-5362-8270

M. Romashchuk

applicant of the second (master's) level of higher education

University of the State Fiscal Service of Ukraine, Irpin, Ukraine

ORCID: 0000-0002-1256-9312

\title{
DEVELOPMENT OF INNOVATIVE-ACTIVE ENTERPRISES OF UKRAINE: MODERN STATUS AND FORECAST
}

\author{
В. Д. Залізко, \\ доктор економічних наук, професор кафедри економіки підприємства, \\ Університет державної фіскальної служби Украӥни, м. Ірпінь, Украӥна \\ М. Б. Ромамук, \\ здобувач другого (магістерського) рівня вищої освіти, \\ Університет державної фіскальної служби України, м. Ірпінь, Украӥна
}

\section{РОЗВИТОК ІННОВАЦИЙНО-АКТИВНИХ ПІДПРИЕМСТВ УКРАЇНИ: СУЧАСНИЙ СТАН ТА ПРОГНОЗ}

It is established that factors that hinder the effective introduction of innovative activities in enterprises under modern conditions are high costs, insufficient funding, long payback period of innovation, vulnerability of property rights, frequent changes in the current legislation.

The stages of planning of innovation activity of foreign companies are determined. It was revealed that the main bearer of innovative entrepreneurship is small business, which involves scientists, technologists, inventors and specialists in the development of innovations.

It has been established that the share of enterprises that implement innovations in Ukraine in 2018 increased compared to 2017, while the number of technological processes increased. It was revealed that the main reason for the low activity of innovation activity is low financial provision of this activity, as well as insufficient level of development of innovation management tools.

The necessity of development and description of the system of management of innovative activity for the enterprises in the conditions of high competition in the market is substantiated.

It is determined that innovative activity of an enterprise plays an important role in maximizing profit. It has been established that factors that impede the effective introduction of innovation activities by enterprises should include too high costs, a long payback period of innovation.

It is substantiated that the innovative activity of an enterprise plays an important role in maximizing profit. The integrated system of management of innovative activity of the enterprise and the mechanism of its realization are considered. The features of innovative activity of modern enterprises are determined. Reasonable methods of stimulating innovation activity.

It was found that the analysis of international practice of application of management systems of innovative activity allows formulating the main tendencies in the innovation branch. The foreign 
experience of application of management systems of innovative activity is offered, stages of planning of innovation activity are defined.

Встановлено, щуо до факторів, які перешкоджають в сучасних умовах ефективно впроваджувати підприємствам інноваційну діяльність, выдносяться занадто високі витрати, недостатність фінансування, тривалий період окупності інновації, незахищеність прав власності, часті зміни чинного законодавства.

Визначені етапи планування інновачійної діяльності зарубіжних компаній. Виявлено, щзо головним носієм інноваційного підприємнищтва є дрібний бізнес, в якому беруть участь вчені, технологи, винахідники і фахівиі з освоєння інновацій.

Встановлено , що питома вага підприємств, які впроваджують інновації, в Україні в 2018 р. зросла порівняно з 2017 р. при ц̧ьому зросла кількість технологічних процесів. Виявлено, щчо основною причиною низької активності інновачійної діяльності $\epsilon$ низьке фінансове забезпечення даної діяльності, а також у недостатній рівень розробки інструментарію інновачійного управління.

Обгрунтовано необхідність розробки та описання системи управління інноваційної діяльності для підприємств в умовах високої конкуренції на ринку.

Визначено, щуо інновачійна активність підприємства відіграє велику роль в максимізації прибутку. Встановлено, шчо до факторів, які перешкоджають ефективно впроваджувати підприємствами інноваційну діяльність, слід віднести занадто високі витрати, тривалий період окупності інновації.

Обгрунтовано, щзо інноваційна активність підприємства відіграє велику роль в максимізації прибутку. Розглянуто інтегровану систему управління інновачійною діяльністю підприємства та механізм ї̈ реалізації. Визначено особливості інноваційної діяльності сучасних підприсмств. Обгрунтовані методи стимулювання інновачійної діяльності.

Виявлено, щуо аналіз міжнародної практики застосування систем управління інноваційною діяльністю дозволяє сформулювати основні тенденції в інноваційній галузі. Запропоновано зарубіжний досвід застосування систем управління інновачійною діяльністю, визначено етапи планування інноваційної діяльності.

Keywords:innovation activity; economic development; innovation development; economic growth; innovative activity.

Ключові слова: інноваційна діяльність; економічний розвиток; інноваційний розвиток; економічне зростання; інтегрована система управління інноваціями.

Formulation of the problem.In today's conditions, one of the important factors in ensuring efficient functioning of enterprises of various spheres is the successful implementation of innovation activities, which allows to ensure the economic development of the enterprise, which in turn requires an increase in innovation activity, an increase in innovative potential and the implementation of purposeful planning, development, introduction and use of innovations.

The share of enterprises that implement innovations in Ukraine in 2018 increased by 2.9 pp compared to 2017, and the number of new technological processes increased by 18 units. However, the introduction of innovations in Ukrainian enterprises, as a rule, is not carried out on a regular basis, but from time to time. The main reasons for the low activity of innovation activity are low financial provision of this activity, as well as in the lack of development of innovative management tools. The above emphasizes the need to develop and describe an innovation management system for enterprises in a highly competitive market.

Actual scientific researches and issues analysis.Innovative activities of enterprises, search for ways to increase its efficiency are the subject of constant scientific research. Basic theoretical and practical aspects of the innovation activity of industrial enterprises have been reflected in the works of domestic and foreign researchers: Andriychuk Yu.A., BiletskaD.O., Vasiliev T.A., Deineka O.G. Denisenko MP, Dovbenko VI, Yegoricheva SB, Zakharchin GM, Illyashenko, MS, Kiselyova IA, Krivich Ya.M., Leonov SV, Nikityuk P.P., Mikhailova L.I., NosenkoD.V. , Primostka L., Tramova A. M. and other.

While paying tribute to the work done by domestic and foreign economists in the field of innovation development, it should be noted that the problem of management of innovation activities did not find its final solution, which determines the relevance of the research topic. Improvement requires a number of questions regarding the use of additional tools for stimulating the introduction of innovative developments. 
Formulating the goals of the article (statement of the task). The purpose of the paper is to determine the dynamics of the current weight of innovation-active enterprises of Ukraine and Ukraine formation of the forecast in the conditions of dictates of socialization .

Presentation of the main research material.Innovative business development is perhaps one of the main needs of the national economy. It is well known that the main purpose of entrepreneurial activity is to maximize profits as the main indicator of activity of enterprises. Innovative activity of an enterprise plays in this one of the most important roles.

Directly innovative enterprises in Ukraine are few. Economic transformations of the 1990's of the twentieth century. were accompanied by a deterioration in the financial situation of domestic enterprises due to a decrease in production volumes and high inflation rates. This led to a catastrophic decline in the innovation activity of industrial enterprises. If the share of enterprises that developed and introduced new or improved existing products in the industry of the former USSR in the late 1980's reached 60-70\%, then this figure in the early 1990's decreased more than three times. In 1992-1995, the share of innovation-active enterprises was in the range of $20-26 \%$, which indicates a significant loss of Ukraine's position among other countries [3, p. 143]. During 2018, 16.2\% of the total number of industrial enterprises engaged in innovation activity, and innovations were implemented - 14.3\% (Fig. 1). It is worth noting that after a significant drop in 2008-2009, these indicators have improved somewhat in recent years.

The largest number of innovation-active enterprises is located in Kyiv, Kharkiv, Zaporozhye, Mykolaiv and Lviv regions. It should be noted that in Ukraine almost $60 \%$ of innovative products are created by enterprises belonging to the third and fourth technological branches [1]. While in developed countries more than $90 \%$ of investments are invested in the fifth and sixth technological developments [2]. At present, in the countries of the European Union (EU), the share of enterprises engaged in innovation activity is about $53 \%$. The largest number of innovative enterprises, among the EU countries, is in Germany (79.3\%), the smallest - in Bulgaria (27.1\% of the total number of enterprises) $[2]$.

\section{Specific weight, $\%$}

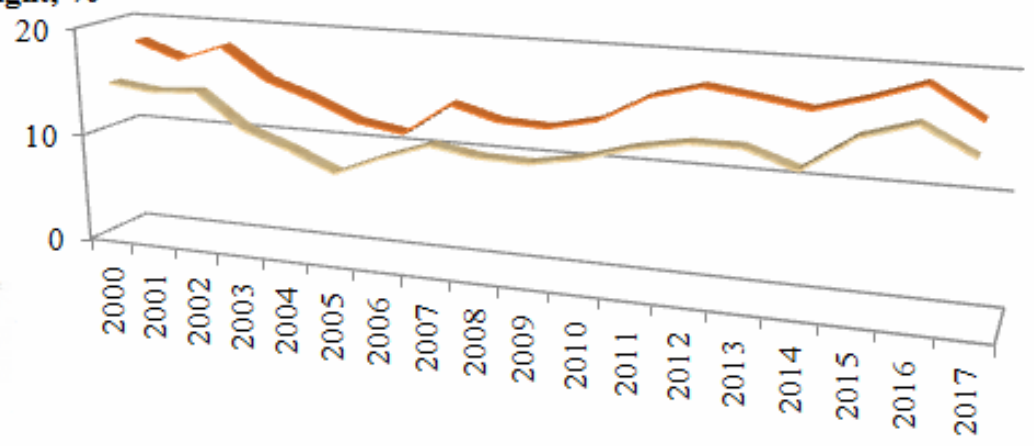

Share of enterprises that implemented innovations, $\%$

- Share of enterprises engaged in innovations, \%

\section{Fig. 1. Dynamics of the share of innovation-active industrial enterprises of Ukraine} (built according to [3])

In the conditions of financial crisis, geopolitical tension, lack of structural reforms, enterprises should not refuse to carry out innovation activities. On the contrary, active introduction of new products into the market that will meet the requirements and needs of consumers will become the basis for stabilizing the position of the company in the market, and in the future ensuring its effective operation.

The factors that impede the effective implementation of innovative activities in enterprises under current conditions include too high costs, lack of financing, long payback period of innovation, vulnerability of property rights, frequent changes in current legislation [ 4, p. 146]. There are also a number of factors that hold back the innovation activity of a particular enterprise, that is, in essence, are internal. These include the lack of staff qualifications, the complexity of controlling innovation costs, and the lack of internal flexibility.

Causes and factors of innovation activity by enterprises:

- the need to ensure profitable activity of the enterprise

- the ability of the company to generate new revenue streams through the introduction of innovative products

- the desire of enterprises to defend their position in the market

- fundamental changes in the structure and nature of the needs of consumers

Environmental factors for innovation:

- Globalization processes

- effective system of risk management

- innovative culture

- level of innovation potential of the enterprise

- frequent changes in the regulation of the activities of business entities

- economic development 
Above The given situation is conditioned by the fact that the implementation of innovations should be based on observance of the principle of effectiveness. The obtaining of competitive advantages, that is, the positive effects from the introduction of innovations, must exceed the costs incurred in their creation and implementation.

Sustainable business development is based on the economic, environmental and social performance of the enterprise by developing solutions in such areas as strategy, management, parameter control and documenting performance.

World experience shows that innovative development is contributed to the comprehensive support of business entities in the field of innovation activity (especially at the initial stage of their formation), creation of conditions for the promotion and introduction of innovations, as well as a set of public and private innovation projects, each of which is able to provide a technological breakthrough in the relevant industry [ 5, p. 263].

In the world economic literature, "innovation" is interpreted as the transformation of potential scientific and technological progress (NTP) into a real, embodied in new products and technologies. In the world practice, it is accepted to innovate organizations, in which more than $70 \%$ of the total volume of production in monetary terms for the reporting tax period is formed at the expense of the production of innovative products [ 6, p. 36].

Incentives can be made through targeted subsidies at the expense of budget funds through federal agencies and agencies, as well as by encouraging the attraction of private capital to finance the innovation activities of small firms and enterprises through venture capital companies formed at the expense of owners.

In the United States, a special kind of entrepreneurship, which is based on scientific and innovative activities, is actively stimulated. The main carrier of innovative entrepreneurship is a small business, which involves scientists, technologists, inventors and specialists in the development of innovations.

In addition, the feature of innovative activity of modern enterprises is the creation of unified scientific and technical complexes, which combine research and production into a single cycle "science - production", which reflects the orientation of innovative developments for market needs, as well as recognition of the significant influence of market factors on strategic state of the enterprise. The data of innovation management systems were first introduced in the largest engineering companies in Japan. In this case, the central services and the branches of innovation development coordinate the respective activities carried out in various production units and central services. In a number of American and Japanese organizations, these tasks are faced with engineering departments, while others specialize in technical centers and services for relations with regional departments [ 7, p. 118-121].

In foreign practice, integrated systems of innovation activity management have become widespread, the essence of which is that the units dealing with the implementation of innovation policy and management of innovations are distributed at different levels of the management structure, but have clear channels of interaction and coordination system.Such an organization of the innovation process allows us to achieve the flexibility of the management structures of innovation activity, which also uses horizontal links between divisions [ 8 ].

Integrated management system for innovation activity of the enterprise is implemented through the compilation and implementation of an innovation program, formulated taking into account the long-term development strategy of the enterprise, its mission, technical policy and industry specificity. Management of innovation activity in the system of this type consists in substantiation of long-term goals of the enterprise, realization of measures in accordance with forecasted opportunities and threats generated by factors of the company's external environment, and also taking into account features of the internal environment: key competences, competitive advantages and weaknesses of business. The strategic orientation of the development of the management system of innovative processes results in the large-scale introduction of new technologies and technology, solving the problems of physical wear and tear and the aging of equipment, products, ideas and increasing the production and economic performance of the enterprise [ 8 ].

For today, the following stages of planning of innovation activity are widespread for foreign companies:

- formulation of the composition of future scheduled problems, the definition of the system of expected hazards or expected capabilities of the enterprise;

- search for alternative solutions of problems;

- the justification of the proposed innovation strategies, goals and objectives that the company plans to implement;

- Planning of the main means to achieve the goals;

- definition of the need for resources;

- designing the implementation of the plans and monitoring their implementation [ 9, p. 53-62] [ 10, p. 5].

A more detailed analysis of international experience in applying innovative systems management systems in organizations is presented in Table 1.

Table 1.

Analysis of foreign experience in the application of innovation management systems

\begin{tabular}{|l|l|l|l|}
\hline \multicolumn{1}{|c|}{ Criteria } & \multicolumn{1}{|c|}{ USA } & \multicolumn{1}{|c|}{ Germany } & \multicolumn{1}{|c|}{ Japan } \\
\hline $\begin{array}{l}\text { The nature of innovation } \\
\text { activity of enterprises }\end{array}$ & $\begin{array}{l}\text { Management of innovative activities on a systematic basis. Level of development of } \\
\text { systems of management of innovative processes in the enterprises - the most important } \\
\text { indicator of the quality of management and the results of the company as a whole }\end{array}$ \\
\hline $\begin{array}{l}\text { Main advantages of } \\
\text { innovation management } \\
\text { systems }\end{array}$ & $\begin{array}{l}\text { Allow to implement large-scale innovative projects, multi- } \\
\text { purpose research, and implement alternative innovations. } \\
\text { There is a rapid introduction of innovative projects, the } \\
\text { formation of multiple innovation management structures, } \\
\text { the use of matrix structures to increase accountability and a }\end{array}$ & $\begin{array}{l}\text { Action ideas, } \\
\text { their rapid dissemination } \\
\text { research, the merger of } \\
\text { production activities into a }\end{array}$ \\
\hline
\end{tabular}




\begin{tabular}{|c|c|c|c|}
\hline & \multicolumn{2}{|c|}{ clear division of functions among qualified professionals. } & \multirow{2}{*}{$\begin{array}{l}\text { unifiedorganizational } \\
\text { knowledge } \\
\text { Shareholders take strategic } \\
\text { decisions and determine the } \\
\text { innovation policy of the } \\
\text { company, managers } \\
\text { implement an innovative } \\
\text { strategy }\end{array}$} \\
\hline & $\begin{array}{l}\text { Shareholders take strategic } \\
\text { decisions and determine the } \\
\text { innovation policy of the } \\
\text { company, managers } \\
\text { implement an innovative } \\
\text { strategy }\end{array}$ & $\begin{array}{l}\text { Shareholders and } \\
\text { management act as one team }\end{array}$ & \\
\hline $\begin{array}{l}\text { The main disadvantages } \\
\text { of } \\
\text { management systems }\end{array}$ & $\begin{array}{l}\text { Significant time costs for } \\
\text { adjusting decisions made in } \\
\text { the field of innovation } \\
\text { policy }\end{array}$ & $\begin{array}{l}\text { The enterprises often lack } \\
\text { the central mechanism that } \\
\text { directs the innovation } \\
\text { activities of the divisions }\end{array}$ & $\begin{array}{l}\text { Insufficient attention to } \\
\text { fundamental research } \\
\text { projects;frequent refusal of } \\
\text { development } \\
\text { introduction of ideas, } \\
\text { innovations } \\
\begin{array}{l}\text { commercial application in } \\
\text { helong-term perspective }\end{array}\end{array}$ \\
\hline $\begin{array}{l}\text { The degree of use of } \\
\text { venture financing }\end{array}$ & $\begin{array}{l}\text { Venture capital is the main e } \\
\text { the enterprise }\end{array}$ & igine of innovation activity of & $\begin{array}{l}\text { Insufficient availability of } \\
\text { venture capital }\end{array}$ \\
\hline \multirow[t]{2}{*}{$\begin{array}{l}\text { The role of the state in the } \\
\text { development of } \\
\text { innovation management } \\
\text { systems }\end{array}$} & \multicolumn{3}{|c|}{$\begin{array}{l}\text { The state is the coordinator of innovation activity of enterprises. } \\
\text { The system of state-private innovation partnership is formed.Innovative business systems } \\
\text { are embedded in national innovation management systems. } \\
\text { The state provides support to enterprises that carry out research, stimulates } \\
\text { entrepreneurship while enterprises take on the commercial risk of implementing innovative } \\
\text { projects }\end{array}$} \\
\hline & $\begin{array}{l}\text { State-funded research is } \\
\text { funded entirely by science- } \\
\text { intensive research }\end{array}$ & $\begin{array}{l}30 \% \text { of all innovation } \\
\text { projects are funded by the } \\
\text { state and local authorities }\end{array}$ & $\begin{array}{l}\text { Active redistribution of } \\
\text { financial resources from the } \\
\text { state budget through } \\
\text { ministries and departments }\end{array}$ \\
\hline \multirow{2}{*}{$\begin{array}{l}\text { Level of involvement of } \\
\text { employees in the } \\
\text { innovation activity of the } \\
\text { enterprise }\end{array}$} & Average & Average & $\begin{array}{l}\text { High: An innovation } \\
\text { management system based } \\
\text { on teamwork }\end{array}$ \\
\hline & \multicolumn{3}{|c|}{$\begin{array}{l}\text { Recognizing the merits of staff in innovative enterprise development is manifested in the } \\
\text { approval of management, access to information, advancement in career ladders, creative } \\
\text { work tasks and self-realization }\end{array}$} \\
\hline
\end{tabular}

An analysis of the international practice of applying innovative systems management systems allows us to formulate the main trends in this field:

- Strengthening the role of the state and company management in defining the principles of national and strategic innovation policy of enterprises respectively;

- globalization of innovation itself;

- Improvement of innovative business management systems at enterprises;

- concentration of basic research and development in scientific and research centers, laboratories, including those supported by the state $[9$, c. 12];

- Lack of Ukrainian enterprises for the development of innovation activity from foreign companies.

Conclusions: Therefore, in order to create a systemic incentive mechanism for innovation activity, it is necessary to study the world experience of stimulating innovation activity and adapt it to the domestic conditions of economic development and to implement it in industry. It is necessary to improve the legal provision of innovations, which will create conditions for the implementation of innovative ideas. It is advisable to develop the infrastructure of the innovation market; to increase the motivation of developers to innovate;strive to achieve the level of innovation, corresponding to the world or exceed it.

To date, Ukraine has already exhausted the reserves of extensive economic growth at the expense of increasing production and export resources, therefore, it is necessary to provide for the settlement of issues hindering the development of innovation activity. A principled combination of these measures will make it possible to determine how 
important the activity of innovation activity in Ukraine is to quickly overcome the consequences of the economic crisis and ensure the effective development of the state. Thus, increasing the competitiveness of the national economy requires a gradual change of its mainly export-raw material structure, reorientation of investment flows into the innovation sphere, implementation of high technologies, formation of the basis for the innovative development model and knowledge economy in Ukraine. The key strategic goal of forming an innovative model for the development of the Ukrainian economy should be the use of modern innovative technologies as the only possible direction for the successful conduct of the competitive struggle of national actors of the government in the domestic and foreign markets.

\section{References.}

1. State Statistics Service of Ukraine (2018), Naukova ta innovatsijna diial'nist' v Ukraini 2017. Statystychnyj zbirnyk [Research and innovation activity in Ukraine 2017. Statistical yearbook], Derzhkomstat, Kyiv, Ukraine.

2. Levchenko, Yu.G. (2016), "Activation of innovation activity of domestic enterprises in the conditions of crisis, available", available

http://eztuir.ztuedu.ua/bitstream/handle/123456789/6813/108.pdf?sequence=1\&isAllowed=y (Accessed 10 May 2019).

3. Official site of the State Statistics Service of Ukraine (2019), available at: http://www.ukrstat.gov.ua/ (Accessed 10 May 2019).

4. Gods, Ya.S. (2012), "Factors that affect the effectiveness of business planning other innovative projects of enterprises", Problems and prospects of development of the banking system of Ukraine, vol. 36, pp. 145-155.

5. Solomatina, N. A. and Slavnetkova, L. B. (2015), "An analysis of the scientific development of innovation systems at the regional level", vol.3, pp. 263-270.

6. Platonov, A.V. (2014), "Efficiency of management of innovations in agriculture", Abstract of Ph.D. dissertation, Economy, Rossijskij gosudarstvennyj agrarnyj zaochnyj universitet, Moscow, Russia.

7. Kirzhner, L.A. Kyenko, L.P. Lepekiko, T.I. and Timonin, A.M. (2006), Menedzhment orhanyzatsyj [Management of organizations], Kyiv, Ukraine.

8. Zagorodnaya, E.P. (2012), "Ananalysis of international experience in the use of basic types of control systems for the innovation unit of the company", available at: https://cyberleninka.ru/article/n/analizmezhdunarodnogo-opyta-primeneniya-osnovnyh-vidov-sistem-upravleniya-innovatsionnoy deyatelnostyu kompanii (Accessed 10 May 2019).

9. Goldstein, G.Y. (2004), Stratehycheskyj innovatsyonnyj menedzhment, [Strategic Innovation Management], Lira, Kyiv, Ukraine.

10 Zalizko, V. D. Fedun, I. L. and Martynenkov, V. I. (2017), "Representative Model of Economic Development for an Agricultural Enterprise in the Context of Socioeconomic Rural Space Formation", Montenegrin Journal of Economics, vol. 13, no. 3, pp. 53-62

\section{Література.}

1. Наукова та інноваційна діяльність // Державна служба статистики України, 2018, URL: http://www.ukrstat.gov.ua/.

2. Левченко Ю.Г. Активізація інноваційної діяльності вітчизняних підприємств в умовах кризи, URL:http://eztuir.ztu.edu.ua/bitstream/handle/123456789/6813/108.pdf?sequence=1\&isAllowed=y, c. 106-111

3. Офіційний сайт Державної служби статистики України, URL : http://www.ukrstat. gov.ua/

4. Богів Я.С. (2012) Фактори, які впливають на ефективність бізнес-планування інноваційних проектів підприємств// Проблеми і перспективи розвитку банківської системи України, №36., С. 145-155, URL: http://nbuv.gov.ua/UJRN/pprbsu_2012_36_18.

5. Соломатіна Н.А., СлавнецковаЛ.В (2015), Анализ зарубежного опыта развития инновационных систем на региональном уровне , № 3, С. 263-270.

6. Платонов А.В. (2014), Эффективность управления инновациями в сельском хозяйстве/, С.145.

7. Киржнер Л.А., Киенко Л.П., Лепейко Т.И., Тимонин А.М. (2006) Менеджмент организаций, К. 115 c.

8. Загороднова Е.П. Анализ международного опыта применения основных видов систем управления инновационной деятельностью компании, (2012). URL: https://cyberleninka.ru/article/n/analiz-mezhdunarodnogoopyta-primeneniya-osnovnyh-vidov-sistem-upravleniya-innovatsionnoy-deyatelnostyu-kompanii, C.98

9. Гольдштейн Г.Я. (2004), Стратегический инновационный менеджмент, К. Ліра. 56 с.

10. Zalizko V. D., Fedun I. L., Martynenkov V. I. (2017) Representative Model of Economic Development for an Agricultural Enterprise in the Context of Socioeconomic Rural Space Formation. Montenegrin Journal of Economics Vol. 13, No. 3. P. 53-62. 